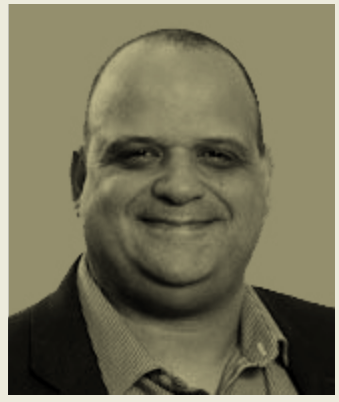

\title{
CONFLITOS AFETIVOS PODEM SER FATAIS ÀS STARTUPS
}

Em pesquisa recente, ainda inédita, identificamos que a maior parte das startups da GVentures que fracassaram durante ou após o processo de aceleração sucumbiu por causa de conflitos entre os sócios fundadores dos empreendimentos. A GVentures, aceleradora da Escola de Administração de Empresas de São Paulo, da Fundação Getulio Vargas (FGV EAESP), é focada em negócios em estágio pre-seed. Nessa fase inicial, em que se busca a validação do produto minimamente viável, por que alguns dos times empreendedores são capazes de administrar os conflitos que surgem enquanto outros não?

Intrigados por essa questão, conduzimos estudos de caso aprofundados com nove das empresas aceleradas entre 2016 e 2019, entrevistando 20 sócios fundadores. Descobrimos que, em todos os casos, ocorreram conflitos operacionais, ou seja, conflitos em relação à condução de processos e tarefas da empresa nascente. É de se esperar que ocorram conflitos dessa natureza em negócios embrionários, entretanto alguns escalam para discussões que comprometem as relações afetivo-pessoais. Embora nem sempre resultem diretamente na dissolução da sociedade, esses conflitos afetivos tendem a interferir na performance dos empreendimentos.

As entrevistas mostraram que os embates entre os sócios foram motivados por: pressões externas, como demandas de investidores, problemas de aceitação do produto no mercado e imposições do processo de aceleração; desalinhamento entre os sócios, como momentos diferentes de vida e visões distintas sobre o propósito do negócio; características pessoais e profissionais, como temperamento e experiência profissional; desconfiança entre os sócios, refletida na descrença na capacidade ou intenção dos sócios; e desacordos no processo de feedback, quando o sócio interpreta a crítica como um ataque pessoal.

Entre esses fatores, a desconfiança entre os sócios e os desacordos no processo de feedback apareceram como os fatores mais corrosivos para a manutenção da sociedade ou do negócio.

Quais caminhos mais parecem contribuir para a manutenção da relação entre os sócios? Nossa pesquisa sugere três estratégias de comunicação: dar uma pausa, desistir do ponto de vista e colocar o ego de lado. Vejamos cada uma delas.

Em alguns casos que pesquisamos, a escalada da discussão, envolvendo conflito afetivo inclusive, foi interrompida quando um dos sócios saiu fisicamente do ambiente do trabalho por algumas horas, ou até mesmo por dias. Os sócios retomaram as discussões posteriormente, de cabeça fria, encontrando soluções para os problemas. Chamamos essa estratégia de dar uma pausa.

A segunda estratégia é desistir do ponto de vista, que ocorre quando, diante de pressões internas ou externas, um dos sócios se dá conta de que é melhor aceitar a proposta ou a visão do outro sócio.

Finalmente, colocar o ego de lado acontece quando cada um dos sócios acredita fortemente que tem a solução para o problema enfrentado, mas, em vez de um tentar provar aos outros que está correto, todos buscam, em conjunto, encontrar uma saída.

Empreendedores em estágio inicial sofrem grande pressão e, nos primeiros meses, o relacionamento entre sócios é colocado em teste todos os dias. Trabalhar em equipe nunca é tarefa fácil. Mesmo em grandes organizações, as estratégias de dar uma pausa, desistir do ponto de vista e colocar o ego de lado podem ser úteis, considerando que a gestão de relacionamentos atualmente envolve equipes complexas. 